GEOSPORT FOR SOCIETY
$\begin{gathered}\text { GEOSPORT } \\ \text { SOCIETY }\end{gathered}$
Scientific Journal founded in 2014 under aegis of University of Oradea (Romania),
University of Debrecen (Hungary), University of Gdánsk (Poland)
ISSN 2393-1353
Edited by Oradea University Press
1, University Street, 410087, Oradea, Romania
Journal homepage: http://geosport.uoradea.ro/geosport.html

\title{
Trends in the lifestyle of students. Case study of a high school in Oradea, Romania
}

\author{
Ștefan ERDELY 1, Tudor CACIORA², Carmen ȘERBESCU ${ }^{3}$, Bianca Mădălina PAPP 4 , \\ Felix Andrei TAMAS 5, Emanuel BUJOREAN 6 , Adriana BAIDOG ${ }^{7}$, Sorin FURDUI 8 , \\ Marius ILE ${ }^{9}$, Grigore Vasile HERMAN ${ }^{10 *}$
}

1. Ady Endre Theoretical High School Oradea, $1^{\text {st }}$ Moscovei Street, Oradea, Romania, e-mail: erdei_istvan@yahoo.com

2. Doctoral School in Geography, University of Oradea, $1^{\text {st }}$ University Street, Oradea, Romania, e-mail: tudor.caciora@yahoo.com

3. University of Oradea, Faculty of Geography, Tourism and Sport, $1^{\text {st }}$ University Street, Oradea, Romania, e-mail: carmen_serbescu@yahoo.com

4. University of Oradea, Faculty of Geography, Tourism and Sport, $1^{\text {st }}$ University Street, Oradea, Romania, e-mail: bianca.papp@yahoo.com

5. University of Oradea, Faculty of Medicine and Pharmacy, Piata 1 Demcembrie, no. 10, Oradea, Romania, e-mail: tamas_andras@yahoo.com

6. Șimian Secondary School, Bihor, Romania, e-mail: emanuelbus@yahoo.com

7. University of Medicine and Pharmacy of Oradea, Municipal Clinical Hospital "Dr G. Curteanu" Nephrology Department, 1 C. Coposu, nr 12, Oradea, Romania, e-mail: bejusca@yahoo.com

8. Doctoral School in Geography, University of Oradea, $1^{\text {st }}$ University Street, Oradea, Romania, e-mail: sorin1182@yahoo.com

9. School No. 2, Călacea, Bihor County, Romania, e-mail: ile.marius@yahoo.com

10. University of Oradea, Department of Geography, Tourism and Territorial Planning, $1^{\text {st }}$ University Street, Oradea, Romania, e-mail: grigoreherman@yahoo.com

* Corresponding author

Citation: Erdely, Ș., Caciora, T., Șerbescu, C., Papp, B.M., Tamas, F.A., Bujorean, E., Baidog, A., Furdui, S., Ile, M., \& Herman, G.V. (2020). Trends in the lifestyle of students. Case study of a high school in Oradea, Romania. Geosport for Society, 12(1), 1-12. https://doi.org/10.30892/gss.1201-052

Article history: Received: 20.09.2019; Revised: 12.11.2019; Accepted: 20.01.2020, Available online: 03.02.2020

Abstract: In a society found in a continuous movement and development, children and teenagers face a more
increased predisposition to adopt a messy lifestyle. Considering this background, the scope of the present study
was to analyse the trends regarding the lifestyle of students from a school in Oradea Municipality, Bihor County,
Romania. For the study were considered 591 students with ages comprised between 10 and 19 years. The
research method used was that of the questionnaire which comprised 15 items regarding their perception of
health, the practice of physical and sedentary activities, rest and nutritiouns habits. The interpretation of results
brings forward the fact that students face great deficiencies regarding their health as a result of a messy lifestyle
characterised by unhealthy nutritious habits, lack of physical activity and corresponding rest and the increase
predisposition towards a sedentary lifestyle. The study materializes as an alarm signal regarding the unhealthy 
Ștefan ERDELY, Tudor CACIORA, Carmen ȘERBESCU, Bianca Mădălina PAPP, Felix Andrei TAMAS, Emanuel BUJOREAN, Adriana BAIDOG, Sorin FURDUI, Marius ILE, Grigore Vasile HERMAN

DOI 10.30892/gss.1201-052

habits of today's students. They do not comply with the standards related to the healthy lifestyle, which can lead in time to the appearance of diseases. In guiding students towards adopting a healthy lifestyle, the most important roles are played by the family and the school.

Keywords: healthy lifestyle, nutrition, student health, health promotion, physical education

\section{Introduction}

Teenagehood is one of the most significant periods in the life of an individual, a period in which ideas, concepts, behaviours and habits develop and may persist for the rest of their life (Post et al., 2001). Modern society faces a great problem concerning the messy lifestyle children and teenagers choose which is characterised by inactivity and a poor nutrition. The results of an undisciplined lifestyle are more and more severe, being the cause of the appearance of chronic diseases such as diabetes, cardiovascular diseases, obesity, different types of cancers or arterial hypertension (Baidog and Herman, 2018; Papp et al., 2019). School, together with family, due to the central role they have in the daily life of each child and teenager, influencing their decisions and shaping their character as future adults (Viner et al., 2012; Buhas, 2015), represent the key to success in what the promotion of positive habits and of a healthy lifestyle is concerned. If it is difficult to control how the family deals with this type of education, through a structured educational system students may be given an insight into positive habits and behaviours concerning nutrition and the practice of physical activities in order to improve and maintain their overall health.

In order to maintain a physical, mental as well as a social wellbeing of the child in an environment which is becoming full of sedentary alternatives, the activity and physical condition play a major role in the context of preventive medicine (Loprinzi et al., 2012; Martinez-Gomes et al., 2010). Moreover, studies carried out in the field (Janssen and LeBlanc, 2010; Verburgh et al., 2013; Biddle and Asare, 2011; Buhaș et al., 2017) have shown that a superior health in adulthood is the result of regulate and systemic practice of physical activities during childhood. One of the primary prophylactic strategies for the improvement of students' physical condition is the increase of physical education classes during a week of study (Moller et al., 2014; Klakk et al., 2013; Demirturk and Kaya, 2015; Buhaș et al., 2018), number of lessons which is relatively low in the curriculum for middle and secondary education in Romania (generally 1 to 2 classes per week).

In what the nutrition is concerned, it represents a fundamental element for an optimum development of children and teenagers (Washi and Ageid, 2010; Moreno et al., 2014). A poor intake of the main nutrients may contribute to a delayed and improper development (Schneider, 2000). As the childhood is the 
period when most of the nutrition habits of an individual are formed, it is important that the school provides its students with support and guidance concerning nutrition and healthy lifestyle (Townsend et al., 2010; Peralta et al., 2016). One of the best known methods used in schools to encourage students to adopt adequate nutrition habits is observed through the implementation of the concept of nutritional education (McKenna, 2010; Graziose et al., 2017; Porter et al., 2017), providing healthy meals for students (Utter et al., 2016) and vitamins (iron, zinc, calcium, vitamin A, vitamin $\mathrm{D}$, vitamin $\mathrm{C}$ ) which provide the necessary supplement for an optimum development (Salam et al., 2016; Noguchi et al., 2018).

Thus, the purpose of the present study is to deal with the analysis and assessment of the tendencies concerning the lifestyle and nutrition of "Ady Endre" High-school students in Oradea, Bihor County, Romania.

\section{Materials and Methods}

\section{Participants:}

The present study is based on the results obtained from the consultation, between the $1^{\text {st }}$ of February 2019 and the 29th of March 2019, of 591 students of the "Ady Endre" Theoretic High-school of Oradea, Bihor County, Romania. The target group comprised 591 students (254 boys and 337 girls) from grades 5 to 12 with ages comprised between 10 and 19 years.

\section{Procedure:}

The used research method was the sociologic survey based on a questionnaire, which is a quantity collection and data analysis method (Babie, 2010; Herman et al., 2019; Ilies et al., 2015; Oneț, 2020; Tătar et al., 2018; Vlăsceanu, 2013; Wendt, 2019). The questionnaire that was used comprised 15 items grouped in two parts. The first part comprises 6 items and assesses the perception of health, the practice of sport, respective sedentary activities and rest (sleep), while the second part comprising 9 items focuses on information regarding the students' dietary habits.

\section{Statistical analyses:}

Data analysis and interpretation was carried out with the help of a statistic analysis software - SPSS. The information thus obtained was analysed (according to their options, sex and grade), in correlation to the results obtained in other speciality studies regarding the analysed elements and the implications they have on health.

\section{Results and Discussions}

At the beginning of the form, the students were required to self-assess their own health by answering the following question "How do you assess your own health?" being able to choose from 5 answers from excellent to unsatisfactory. Studies carried out in this domain prove that the family support is a powerful 
predictor of perception on the health of a teenager (Peres et al., 2010; Meireles et al., 2015; Dragoș et al., 2018), indicating thus the importance of the family during the development of the individual. The question being increasingly subjective, as it has been already expected, more than three quarters of the respondents $(86.28 \%-510$ students) declared to be pleased with their health, choosing the answers "excellent", "very good" and "good". The percentages are rather balanced considering the satisfaction degree of the health according to gender; with a slight difference, girls are $2.45 \%$ more satisfied than boys. To be noticed the increase tendency of the unsatisfaction once they get older. If $90.7 \%$ of the students from grades $5-8$ are satisfied with their health, the proportion decreases in the case of high-school students (grades 9 - 12), where only $82.9 \%$ are satisfied (table 1 ).

In order to have a healthy lifestyle and an optimum development, children and teenagers should practise at least 60 minutes of physical activity every day, with an intensity from moderate to vigorous (Hills et al., 2015; Martinez-Gomez et al., 2010; Tătar et al., 2018; Marcu and Buhaș, 2011).

Following the analysis of the results obtained by applying the questionnaire, there were observed deficiencies regarding the time allotted by the students to practice physical activities. Most of the students answered the question "How often do you practice physical activity?" with 2-3 times per week (41.45\% - 235 students), followed by those who practice it daily $(25.67 \%$ - 150 students $)$ and once a week (15.13\% - 94 students). Out of the total of 591 respondents, 75 rarely practise a physical activity, while 37 do not practise an activity at all. A 15\% deficit is observed between the two education cycles, therefore, in grades 5 to $8,89.9 \%$ practise a sport weekly, while at a high-school level the proportion decreases to $74.5 \%$. The $7^{\text {th }}$ graders are the students who practise a physical activity the most, where $90.56 \%$ practise it daily or at least twice per week. The $12^{\text {th }}$ graders are at the opposite pole, where $14.89 \%$ do not practice any sport, while $21.28 \%$ declared that they do practise a sport but very rarely. The percentages are balanced when analysing the genders; $83.08 \%$ of the boys practise a physical activity at least once a week (31.34 daily, $41.96 \%$ - 2-3 times a week, $9.78 \%$ - once a week), while the percentage for girls is 80.75 (18.76\% - daily, $42.67 \%$ - 2 - 3 times a week, $19.32 \%$ - once a week).

Sleep is essential for the body to recover and to increase the attention span and memorisation capacity. A report of the National Sleep Foundation, published in 2000, reveals that teenagers require between 8.5 and 9.25 hours of sleep every night. Decreasing the effective sleep period may lead to metabolic imbalances and hormonal changes in time (Pulido-Arjona et al., 2018), contributing also to the appearance of obesity (Magee and Hale, 2012). Most of the students questioned (44.90\% - 265 students) declared that they sleep less than 8 hours per night, while 
those who sleep between 8 and 9 hours per night are 312. Considering the optimum number of hours slept in relation with the grade, it may be observed that there is a continuous decreasing trend. Therefore, most of the $5^{\text {th }}$ graders $(86.49 \%)$ respect the recommendations concerning the sleep period while only $11.11 \%$ of the $12^{\text {th }}$ graders sleep between 8 and 9 hours per night.

Table 1. Students' answers to questions about their lifestyle

\begin{tabular}{|c|c|c|c|c|c|c|c|c|c|c|c|}
\hline \multirow{2}{*}{ Questions } & \multirow{2}{*}{$\begin{array}{l}\text { Answer } \\
\text { options }\end{array}$} & \multicolumn{8}{|c|}{ Students answers by classes (\%) } & \multirow{2}{*}{$\begin{array}{l}\text { Total } \\
\text { (no.) }\end{array}$} & \multirow{2}{*}{$\begin{array}{c}\text { Averag } \\
\text { e (\%) }\end{array}$} \\
\hline & & $\mathbf{V}$ & VI & VII & VIII & IX & $\mathrm{X}$ & $\mathbf{X I}$ & XII & & \\
\hline \multirow{5}{*}{$\begin{array}{c}\text { How do you } \\
\text { assess your own } \\
\text { health? }\end{array}$} & excellent & 9.30 & 0.00 & 5.56 & 5.88 & 3.74 & 3.92 & 2.88 & 0.00 & 23 & 3.91 \\
\hline & very good & 32.56 & 36.11 & 53.70 & 50.98 & 32.71 & 33.33 & 36.54 & 31.25 & 227 & 38.40 \\
\hline & good & 48.84 & 47.22 & 33.33 & 39.22 & 47.66 & 47.06 & 38.46 & 50.00 & 260 & 43.97 \\
\hline & satisfactory & 9.30 & 13.89 & 7.41 & 3.92 & 14.95 & 14.71 & 17.31 & 14.58 & 71 & 12.01 \\
\hline & unsatisfactory & 0.00 & 2.78 & 0.00 & 0.00 & 0.94 & 0.98 & 4.81 & 4.17 & 10 & 1.71 \\
\hline \multirow{5}{*}{$\begin{array}{l}\text { How often do you } \\
\text { practice physical } \\
\text { activity? }\end{array}$} & daily & 36.36 & 19.15 & 45.28 & 27.27 & 36.96 & 17.82 & 9.71 & 12.77 & 150 & 25.67 \\
\hline & 2-3 times/week & 45.45 & 53.19 & 45.28 & 47.27 & 26.81 & 34.65 & 53.40 & 25.53 & 235 & 41.45 \\
\hline & 1 times/week & 11.36 & 12.77 & 1.89 & 14.55 & 16.67 & 22.77 & 15.53 & 25.53 & 94 & 15.13 \\
\hline & rare & 6.82 & 10.64 & 3.77 & 9.09 & 13.04 & 16.83 & 14.56 & 21.28 & 75 & 12.00 \\
\hline & don't practice & 0.00 & 4.26 & 3.77 & 1.82 & 6.52 & 7.92 & 6.80 & 14.89 & 37 & 5.75 \\
\hline \multirow{5}{*}{$\begin{array}{l}\text { How many hours } \\
\text { do you usually } \\
\text { sleep at night? }\end{array}$} & $\begin{array}{c}\text { less than } 8 \\
\text { hours }\end{array}$ & 5.41 & 35.14 & 21.57 & 21.15 & 47.68 & 62.64 & 76.70 & 88.89 & 265 & 44.90 \\
\hline & 8 hours & 56.76 & 24.32 & 54.90 & 36.54 & 18.54 & 29.67 & 22.33 & 11.11 & 188 & 31.77 \\
\hline & 9 hours & 29.73 & 35.14 & 19.61 & 40.38 & 33.77 & 7.69 & 0.97 & 0.00 & 124 & 20.91 \\
\hline & 10 hours & 5.41 & 0.00 & 3.92 & 1.92 & 0.00 & 0.00 & 0.00 & 0.00 & 8 & 1.41 \\
\hline & $\begin{array}{c}\text { more than } 10 \\
\text { hours }\end{array}$ & 2.70 & 5.41 & 0.00 & 0.00 & 0.00 & 0.00 & 0.00 & 0.00 & 6 & 1.01 \\
\hline \multirow{5}{*}{$\begin{array}{l}\text { What time do you } \\
\text { go to bed in the } \\
\text { evening? }\end{array}$} & before 9 o'clock & 22.73 & 13.89 & 11.32 & 1.85 & 4.03 & 4.85 & 0.98 & 0.00 & 44 & 7.46 \\
\hline & $22: 00$ & 50.00 & 63.89 & 41.51 & 38.89 & 18.55 & 21.36 & 17.65 & 14.89 & 197 & 33.34 \\
\hline & $23: 00$ & 27.27 & 22.22 & 43.40 & 46.30 & 41.13 & 32.04 & 40.20 & 34.04 & 211 & 35.83 \\
\hline & $24: 00$ & 0.00 & 0.00 & 3.77 & 9.26 & 30.65 & 34.95 & 32.35 & 36.17 & 109 & 18.39 \\
\hline & after 12 o'clock & 0.00 & 0.00 & 0.00 & 3.70 & 5.65 & 6.80 & 8.82 & 14.89 & 30 & 4.98 \\
\hline \multirow{5}{*}{$\begin{array}{l}\text { How often do you } \\
\text { have problems } \\
\text { with the sleep? }\end{array}$} & daily & 11.36 & 8.33 & 20.37 & 15.09 & 37.78 & 23.30 & 15.00 & 19.57 & 111 & 18.85 \\
\hline & 2-3 times/week & 36.36 & 36.11 & 27.78 & 35.85 & 32.59 & 40.78 & 33.00 & 26.09 & 198 & 33.57 \\
\hline & 1 times/week & 15.91 & 16.67 & 3.70 & 11.32 & 11.85 & 14.56 & 19.00 & 17.39 & 82 & 13.80 \\
\hline & rare & 29.55 & 13.89 & 42.59 & 22.64 & 12.59 & 13.59 & 23.00 & 26.09 & 136 & 22.99 \\
\hline & never & 6.82 & 25.00 & 5.56 & 15.09 & 5.19 & 7.77 & 10.00 & 10.87 & 64 & 10.79 \\
\hline \multirow{5}{*}{$\begin{array}{l}\text { How many hours } \\
\text { a day do you } \\
\text { spend at the } \\
\text { computer/smartp } \\
\text { hone/television? }\end{array}$} & $\begin{array}{c}\text { less than } 2 \\
\text { hours }\end{array}$ & 30.95 & 27.78 & 23.08 & 20.41 & 16.79 & 20.20 & 11.34 & 6.52 & 116 & 19.63 \\
\hline & 2 hours & 33.33 & 41.67 & 42.31 & 32.65 & 30.53 & 37.37 & 25.77 & 21.74 & 196 & 33.17 \\
\hline & 3 hours & 14.29 & 13.89 & 21.15 & 22.45 & 38.93 & 25.25 & 34.02 & 17.39 & 138 & 23.42 \\
\hline & 4 hours & 16.67 & 11.11 & 9.62 & 20.41 & 8.40 & 10.10 & 8.25 & 26.09 & 82 & 13.83 \\
\hline & $\begin{array}{c}\text { more than } 4 \\
\text { hours }\end{array}$ & 4.76 & 5.56 & 3.85 & 4.08 & 5.34 & 7.07 & 20.62 & 28.26 & 59 & 9.94 \\
\hline
\end{tabular}

There is an irregularity which might be observed following the analysis of the data collected for the following question "What time do you go to bed in the evening?". Studies have revealed that the optimum sleep interval for children and teenagers is between 9 o'clock in the evening and 7 - 8 o'clock in the morning (Short et al., 2011), while the people who go to sleep between 9 and 10 o'clock at night obtain better results in attention, memory and creativity tests compared to those who sleep the same number of hours but go to sleep later. Only $40.80 \%$ of the students of "Ady Endre" High-school of Oradea comply with the recommended norms and go to sleep by 10 o'clock at night. The rest of $59.20 \%$ go to sleep later, some of them exceeding 11 o'clock at night. The middle school students respect the recommendations the most (61\% go to sleep before 10 o'clock) especially students in $5^{\text {th }}$ and $6^{\text {th }}$ grade, while the percentage for the students in high-school drops to 
$20.58 \%$, with the minimum value in the last grade of high-school $(14.89 \%)$. The sleep deficiencies are also frequent in students, $66.22 \%$ of them reporting sleep problems every week. Approximately 111 (18.85\%) of the questioned students have sleep problems every night, 198 (33.57\%) twice or three times per week and 82 $(13.80 \%)$ students once a week. Having analysed the data in relation to the education cycles it is revealed that high-school students are predisposed to having frequent insomnias (72.73\%), compared to middle school students (59.71\%). This is a problem which requires serious treatment both by the students as well as by their parents as insomnias may have devastating effects on health. Teenagers who lose nights are prone to develop chronic depression, behavioural imbalances, social adaptation deficit, dealing with intellectual performances decrease, lack of reactivity and cognitive functions (Owens, 2014; Buhaș, 2015).

Together with the progress of digital technology, teenagers have started to occupy their free time surfing the web, communicating with each other through socialising networks or simply watching television. The American Paediatric Academy does not recommend that students spend more than two hours using their smartphone, computer or television (Rosen et al., 2014). Abuse may lead in time to psychologic stress, manifested through depression, withdrawal, anxiety, attention problems, aggressiveness, sadness, suicidal thoughts, as well as physical imbalances (backpain, migraines, obesity) (Bailin et al., 2014). Half of the students questioned (52.81\% - 312 students) reported using electronic devices no more than two hours a day. This has been especially reported by middle school students $(63.05 \%)$ and less by high-school students (42.57\%). But the later are more predisposed to abuse than the small ones; $42.11 \%$ of the high-school children use their devices between 3 and 4 hours every day, while $15.32 \%$ use their devices more than 4 hours every day.

The analysis of the answers for the questions which assess nutrition and dietary habits of students and teenagers (table 2) reveal a series of irregularities, as well as corresponding behaviour towards the consumption of food; which is hopeful for the present and future health of children.

Not to serve breakfast is a worldwide phenomenon, while teenagers from the target group of the present study carry out this unhealthy habit. Only $111(18.85 \%)$ students of the total of 591 have breakfast every day, while $82(13.80 \%)$ do this thing twice or three times per week. Most of them (33.57\%) eat in the morning once a week, and in special cases (22.99\%), or skip breakfast (10.79\%) (table 2). Recent studies (Alexy et al., 2010; Sila et al., 2019; Fayet-Moore et al., 2016) have raised a warning signal concerning this unhealthy habit which may lead to obesity, attention deficit and the decrease of school performances. 
Table 2. Students' answers to questions about the nutrition habits

\begin{tabular}{|c|c|c|c|c|c|c|c|c|c|c|c|}
\hline \multirow{2}{*}{ Questions } & \multirow{2}{*}{ Answer options } & \multicolumn{8}{|c|}{ Students answers by classes (\%) } & \multirow{2}{*}{$\begin{array}{l}\text { Total } \\
\text { (no.) }\end{array}$} & \multirow{2}{*}{$\begin{array}{c}\text { Averag } \\
\text { e (\%) }\end{array}$} \\
\hline & & V & VI & VII & VIII & IX & $\mathrm{X}$ & $\mathbf{X I}$ & XII & & \\
\hline \multirow{5}{*}{$\begin{array}{l}\text { How often do you serve } \\
\text { a consistent breakfast? }\end{array}$} & daily & 11.36 & 8.33 & 20.37 & 15.09 & 37.78 & 23.30 & 15.00 & 19.57 & 111 & 18.85 \\
\hline & 2-3 times/week & 15.91 & 16.67 & 3.70 & 11.32 & 11.85 & 14.56 & 19.00 & 17.39 & 82 & 13.80 \\
\hline & 1 times/week & 36.36 & 36.11 & 27.78 & 35.85 & 32.59 & 40.78 & 33.00 & 26.09 & 198 & 33.57 \\
\hline & rare & 29.55 & 13.89 & 42.59 & 22.64 & 12.59 & 13.59 & 23.00 & 26.09 & 64 & 22.99 \\
\hline & never & 6.82 & 25.00 & 5.56 & 15.09 & 5.19 & 7.77 & 10.00 & 10.87 & 136 & 10.79 \\
\hline \multirow{5}{*}{$\begin{array}{c}\text { How often do you eat } \\
\text { vegetables? }\end{array}$} & daily & 11.63 & 33.33 & 27.45 & 46.15 & 40.48 & 27.45 & 25.74 & 29.79 & 179 & 30.25 \\
\hline & 2-3 times/week & 53.49 & 53.85 & 62.75 & 44.23 & 46.03 & 55.88 & 58.42 & 61.70 & 322 & 54.54 \\
\hline & 1 times/week & 13.95 & 10.26 & 7.84 & 7.69 & 10.32 & 11.76 & 10.89 & 6.38 & 59 & 9.89 \\
\hline & rare & 11.63 & 2.56 & 1.96 & 1.92 & 2.38 & 3.92 & 4.95 & 2.13 & 23 & 3.93 \\
\hline & never & 9.30 & 0.00 & 0.00 & 0.00 & 0.79 & 0.98 & 0.00 & 0.00 & 8 & 1.38 \\
\hline \multirow{5}{*}{$\begin{array}{l}\text { How often do you eat } \\
\text { fruit? }\end{array}$} & daily & 38.64 & 50.00 & 35.85 & 22.22 & 40.80 & 29.41 & 34.00 & 44.68 & 218 & 36.95 \\
\hline & 2-3 times/week & 38.64 & 27.78 & 45.28 & 66.67 & 41.60 & 49.02 & 44.00 & 42.55 & 263 & 44.44 \\
\hline & 1 times/week & 11.36 & 16.67 & 11.32 & 11.11 & 13.60 & 16.67 & 13.00 & 8.51 & 76 & 12.78 \\
\hline & rare & 9.09 & 5.56 & 7.55 & 0.00 & 3.20 & 3.92 & 7.00 & 2.13 & 28 & 4.81 \\
\hline & never & 2.27 & 0.00 & 0.00 & 0.00 & 0.80 & 0.98 & 2.00 & 2.13 & 6 & 1.02 \\
\hline \multirow{5}{*}{$\begin{array}{c}\text { How often do you eat } \\
\text { meat or meat } \\
\text { preparations? }\end{array}$} & daily & 31.11 & 30.56 & 18.52 & 20.75 & 38.35 & 23.30 & 14.71 & 12.77 & 140 & 23.76 \\
\hline & 2-3 times/week & 37.78 & 19.44 & 40.74 & 32.08 & 33.08 & 43.69 & 43.14 & 48.94 & 221 & 37.36 \\
\hline & 1 times/week & 17.78 & 11.11 & 18.52 & 16.98 & 9.02 & 10.68 & 5.88 & 6.38 & 71 & 12.04 \\
\hline & rare & 8.89 & 27.78 & 12.96 & 15.09 & 15.04 & 17.48 & 23.53 & 17.02 & 102 & 17.22 \\
\hline & never & 4.44 & 11.11 & 9.26 & 15.09 & 4.51 & 4.85 & 12.75 & 14.89 & 57 & 9.61 \\
\hline \multirow{5}{*}{$\begin{array}{l}\text { How often do you eat } \\
\text { sweets? }\end{array}$} & daily & 32.56 & 25.00 & 33.33 & 50.00 & 45.13 & 41.00 & 25.49 & 25.53 & 205 & 34.76 \\
\hline & 2-3 times/week & 34.88 & 38.89 & 45.10 & 38.46 & 39.82 & 42.00 & 33.33 & 38.30 & 230 & 38.85 \\
\hline & 1 times/week & 16.28 & 16.67 & 13.73 & 3.85 & 9.73 & 11.00 & 23.53 & 21.28 & 86 & 14.51 \\
\hline & rare & 16.28 & 16.67 & 7.84 & 5.77 & 5.31 & 6.00 & 16.67 & 14.89 & 66 & 11.18 \\
\hline & never & 0.00 & 2.78 & 0.00 & 1.92 & 0.00 & 0.00 & 0.98 & 0.00 & 4 & 0.71 \\
\hline \multirow{5}{*}{$\begin{array}{c}\text { How often do you eat } \\
\text { pastry? }\end{array}$} & daily & 18.18 & 8.33 & 5.77 & 18.52 & 34.69 & 6.73 & 6.00 & 9.30 & 79 & 13.44 \\
\hline & 2-3 times/week & 50.00 & 36.11 & 40.38 & 38.89 & 36.05 & 50.96 & 44.00 & 32.56 & 243 & 41.12 \\
\hline & 1 times/week & 22.73 & 30.56 & 34.62 & 27.78 & 19.73 & 27.88 & 28.00 & 25.58 & 160 & 27.11 \\
\hline & rare & 9.09 & 22.22 & 15.38 & 14.81 & 9.52 & 14.42 & 21.00 & 32.56 & 103 & 17.38 \\
\hline & never & 0.00 & 2.78 & 3.85 & 0.00 & 0.00 & 0.00 & 1.00 & 0.00 & 6 & 0.95 \\
\hline \multirow{4}{*}{$\begin{array}{l}\text { How often do you eat } \\
\text { foods with high } \\
\text { saturated fat and } \\
\text { cholesterol? }\end{array}$} & daily & 9.09 & 0.00 & 7.55 & 5.66 & 7.14 & 10.38 & 7.07 & 4.35 & 38 & 6.41 \\
\hline & 2-3 times/week & 38.64 & 55.56 & 47.17 & 49.06 & 39.61 & 60.38 & 60.61 & 56.52 & 301 & 50.94 \\
\hline & 1 times/week & 52.27 & 41.67 & 45.28 & 45.28 & 20.13 & 29.25 & 31.31 & 39.13 & 225 & 38.04 \\
\hline & rare & 0.00 & 2.78 & 0.00 & 0.00 & 33.13 & 0.00 & 1.01 & 0.00 & 27 & 4.62 \\
\hline \multirow{5}{*}{$\begin{array}{l}\text { How often do you eat } \\
\text { high processed foods } \\
\text { (carbonated drinks, fast } \\
\text { food etc.)? }\end{array}$} & daily & 8.89 & 27.78 & 9.43 & 17.31 & 18.52 & 23.53 & 20.19 & 17.02 & 105 & 17.83 \\
\hline & 2-3 times/week & 24.44 & 27.78 & 41.51 & 30.77 & 28.15 & 36.27 & 38.46 & 29.79 & 190 & 32.15 \\
\hline & 1 times/week & 24.44 & 22.22 & 13.21 & 19.23 & 37.78 & 18.63 & 12.50 & 19.15 & 124 & 20.90 \\
\hline & rare & 42.22 & 22.22 & 35.85 & 32.69 & 14.07 & 18.63 & 27.88 & 31.91 & 166 & 28.18 \\
\hline & never & 0.00 & 0.00 & 0.00 & 0.00 & 1.48 & 2.94 & 0.96 & 2.13 & 6 & 0.94 \\
\hline \multirow{5}{*}{$\begin{array}{l}\text { How much water do } \\
\text { you drink during a day? }\end{array}$} & $\begin{array}{c}\text { less than } 1,5 \\
\text { litre }\end{array}$ & 20.93 & 33.33 & 19.23 & 13.21 & 19.85 & 25.00 & 22.55 & 32.65 & 138 & 23.34 \\
\hline & 1,5 litre & 44.19 & 33.33 & 40.38 & 43.40 & 30.15 & 38.00 & 42.16 & 24.49 & 219 & 37.01 \\
\hline & 2 litre & 27.91 & 13.89 & 26.92 & 22.64 & 37.50 & 21.00 & 27.45 & 28.57 & 152 & 25.74 \\
\hline & 2,5 litre & 4.65 & 16.67 & 13.46 & 13.21 & 6.62 & 8.00 & 6.86 & 14.29 & 62 & 10.47 \\
\hline & $\begin{array}{l}\text { more than } 2,5 \\
\text { litre }\end{array}$ & 2.33 & 2.78 & 0.00 & 7.55 & 5.88 & 8.00 & 0.98 & 0.00 & 20 & 3.44 \\
\hline
\end{tabular}

A satisfying thing is the fact that the students questioned acknowledge the importance of fruit and vegetables for a balanced and healthy diet. Over $80 \%$ of the students declare they eat fruit and vegetables at least twice a week, while $30 \%$ of them do it daily. Only 8 subjects do not eat vegetables at all, while 6 do not eat any fruit. Even if vegetables are a good source of fibres, they stimulate the transit with essential implications for the somatic and psychic balance, but also meat has an important role in a diet. Meat consumption also has beneficial effects, providing the proteins and nutrients essential for the organism, but it has to be consumed wisely and to avoid excesses in order to avoid heart problems and arterial hypertension (Wyness, 2015); also, the choice of the type of meat is very important. The majority of the students (37.36\%) maintain an optimum ratio of meat in their diet, consuming it two to three times per week. Approximately a quarter of the students 
abuse it, consuming it daily, while 57 students never eat meat or meat produce. The biggest consumers are the students of the 5 th grade, $86.67 \%$ eating meat weekly, followed by $9^{\text {th }}$ graders $(80.45 \%)$ and $7^{\text {th }}$ graders $(77.78 \%)$; while on the opposite pole are the $6^{\text {th }}$ graders $(61.11 \%)$ and the $12^{\text {th }}$ grades $(68.09 \%)$.

Sweets, as it was expected, are the students' favourite, approximately a third (34.76\% - 205 students) consume them daily, while 38.85\% twice or three times per week. This is the question which has received the lowest number of "never" answers, only 4 subjects never consume sweets.

Bakery products are also present in the weekly menu of children and teenagers, being consumed especially during school days. Over $80 \%$ (482 students) have reported to consume this type of products at least once per week, most of them (41.12\% - 243 students) even two to three times per week. A decreasing trend of the number of consumers in middle school may be observed, until the last grade of highschool where the minimum threshold is recorded (67.44\%).

Students frequently consume foods rich in saturated fats and cholesterol, as well as highly processed foods. Approximately 95\% eat produce rich in saturated fats at least once a week, the favourite answer being "2 - 3 times/week" with 301 respondents. Only $4.62 \%$ of those questioned rarely consume such types of foods; most of them are $9^{\text {th }}$ graders, $33 \%$ of the total. Highly processed foods such as frozen semi-cooked foods, carbonated drinks, fast food, etc. are consumed on a weekly basis by most of the students. Therefore, an average of $70.88 \%$ of the 591 students consume this type of foods at least once a week, the largest number (32.15\%) even twice or three times a week, while $17.83 \%$ consume them daily. The analysis based on education cycles reveals that high-school students (75\%) are most likely prone to consume this type of products compared to the percentage of middle school students $(66.75 \%)$.

Sweets, bakery products, foods rich in saturated fats and highly processed foods, due to the fact that they are nutritionally imbalanced (Louzada et al., 2015), frequently consumed and in large quantities may represent a real danger for children and teenagers. The most frequent negative effects are obesity, different types of cancer (hepatic, colic, renal etc.), increase in the level of cholesterol and triglycerides, fatigue, lack of concentration, decrease in focus and reaction speed (Powell and Nguyen, 2013).

Water is an essential nutrient for optimal functioning of the body. The 2010 report of the European Food Safety Authority (EFSA) regarding Dietetic Products, Nutrition and Allergies reveals that for a healthy lifestyle, children and teenagers are required to drink between 2 and 2.5 litres of water per day, depending on their sex, age, weight and physical activity. Only 39.65\% (234 students) of those questioned 
meet the requirements of this standard. The majority (37.01\%), consume only 1.5 litres of water per day, which is quite a small amount of water even for a middle school child. As it was expected, the water consumption increases in direct relation with the age, high-school students consume more water than middle school students. There is an alarming issue concerning the water consumption of students, because the effects of dehydration are very dangerous. EFSA reveals as a consequence of low water consumption, symptoms such as: headaches, irritability, concentration difficulties, drowsiness, muscle cramps, etc.

\section{Conclusions}

The inadequate lifestyle, lack of physical activity and an unhealthy diet may contribute in time to the serious degradation of children's health. This study is seen as an alarm signal concerning unhealthy behaviours of children and teenagers nowadays. A series of problems which the students face were identified as a result of the application of the questionnaire. Concerning the feeding habits few of the teenagers questioned respect the standards and norms imposed by the main intake of nutrients. Their nutrition is a chaotic one, sprung either from their or their parents' carelessness. Also, students prefer to use electronic devices instead of practicing a sport, they sleep less and most of them have sleep related problems. All these may contribute in time to the decrease in school performance as well as the increase in a predisposition to develop different affections. The school has a major role considering the fight against this negative trend related to an unbalanced diet and an unhealthy lifestyle, which seems to have been appropriated by a large number of children and teenagers. Also the introduction within the curricula of diet related classes, as well as a greater number of physical education lessons ensures the promotion of a healthy lifestyle and also assists children and parents to counteract present lacks.

\section{References}

Alexy, U., Wicher, M., \& Kersting, M. (2010). Breakfast trends in children and adolescents: frequency and quality. Public Health Nutrition, 13(11), 1795-1802.

Babbie, E. (2010). The Practice of Social Research (In Romanian), Polirom Publishing House Iași.

Baidog, A., \& Herman, G.V. (2018). The Influence of Sports and Physical Activity on the Metabolic Syndrome: A Systematic Review. Analele Universităţii din Oradea. Fascicula Educaţie Fizică şi Sport, 28(1), 39-45.

Bailin, A., Milanaik, R., \& Adesman, A. (2014). Health implications of new age technologies for adolescents. Current Opinion in Pediatrics, 26(5), 605-619.

Biddle, S. J. H., \& Asare, M. (2011). Physical activity and mental health in children and adolescents: a review of reviews. British Journal of Sports Medicine, 45(11), 886-895.

Buhaș, S. (2015). Sport and physical education - Forms of socialization. GeoSport for Society, 3 (2), 53-60. 
Ștefan ERDELY, Tudor CACIORA, Carmen ȘERBESCU, Bianca Mădălina PAPP, Felix Andrei TAMAS, Emanuel BUJOREAN, Adriana BAIDOG, Sorin FURDUI, Marius ILE, Grigore Vasile HERMAN

DOI 10.30892/gss.1201-052

Buhaș, S. (2015). The social impact of sports activities. Studia Universitatis "Vasile Goldiș"seria Educație Fizică și Kinetoterapie, 2(8), 27-33.

Buhaș, S., Herman, G.V., Dragoș, P.F., \& Stance, L. (2017). Footbal and economy before and after communism in Romania. GeoSport of Society, 6 (1), 30-39.

Buhaș, S., Herman, G.V., \& Ștef, M. (2018). Aspects regarding speed development in football game in 1214 yers old children. GeoSport for Society, 8 (1), 21-30.

Demirturk, F., \& Kaya, M. (2015). Physical Education Lessons and Activity Status of Visually Impaired and Sighted Adolescents. Medical Science Monitor, 21, 3521-3527.

Dragoș, P.F., Lucaciu, G., Dinis, I., Ștef, M., Szabo-Alexi, P., \& Buhaș, S. (2018). Concepts concerning the content of children`s trainind in some sport games. Proceedings of the $4^{\text {th }}$ international conference of the Universitaria Consortium ( ICU 2018): The impact of sport and physical education science on today's society, 67-72. Editografica SRL, Intl Proceedings Div, Via G Verdi 15, Pianoro, Bologna 1-40065, Italy.

EFSA Panel on Dietetic Products, Nutrition, and Allergies (NDA). (2010). Scientific opinion on dietary reference values for water. EFSA Journal, 8(3), 1459.

Fayet-Moore, F., Kim, J., Sritharan, N., \& Petocz, P. (2016). Impact of breakfast skipping and breakfast choice on the nutrient intake and body mass index of Australian children. Nutrients, 8(8), 487.

Graziose, M. M., Koch, P. A., Wang, Y. C., Lee Gray, H., \& Contento, I. R. (2017). Cost-effectiveness of a Nutrition Education Curriculum Intervention in Elementary Schools. Journal of Nutrition Education and Behavior, 49(8), 684-691.

Herman, G. V., Wendt, A. J., Dumbravă, R., \& Gozner, M. (2019). The role and importance of promotion centers in creating the image of tourist destination: Romania. Geographia Polonica, 92(4), 443-454.

Hills, A. P., Dengel, D. R., \& Lubans, D. R. (2015). Supporting Public Health Priorities: Recommendations for Physical Education and Physical Activity Promotion in Schools. Progress in Cardiovascular Diseases, 57(4), 368-374.

Ilieș, D.C., R. Buhaș, A. Ilies, C. Morar, \& Herman, G.V. (2015). Nymphaea Lotus Var. Thermalis (Pârâul Pețea nature reserve), Brand Near Extinction of the Băile Felix-Băile 1 Mai (Romania) Spa Tourism System. Geojournal of Tourism and Geosites, 15(1), 107-117.

Janssen, I., \& LeBlanc, A.G., (2010). Systematic review of the health benefits of physical activity and fitness in school-aged children and youth. International Journal of Behavioral Nutrition and Physical Activity, 7(40), 1-16.

Klakk, H., Andersen, L. B., Heidemann, M., Møller, N. C., \& Wedderkopp, N. (2013). Six physical education lessons a week can reduce cardiovascular risk in school children aged 6-13 years: A longitudinal study. Scandinavian Journal of Public Health, 42(2), 128-136.

Loprinzi, P. D., Cardinal, B. J., Loprinzi, K. L., \& Lee, H. (2012). Benefits and Environmental Determinants of Physical Activity in Children and Adolescents. Obesity Facts, 5(4), 597-610.

Louzada, M. L. da C., Baraldi, L. G., Steele, E. M., Martins, A. P. B., Canella, D. S., Moubarac, J.-C., ... Monteiro, C. A. (2015). Consumption of ultra-processed foods and obesity in Brazilian adolescents and adults. Preventive Medicine, 81, 9-15.

Magee, L., \& Hale, L. (2012). Longitudinal associations between sleep duration and subsequent weight gain: A systematic review. Sleep Medicine Reviews, 16(3), 231-241

Marcu, V., Buhaș, S. (2011). Systematic analysis of sports activity. Discobolul, 26(4), 35-42.

Martinez-Gomez, D., Ruiz, J. R., Ortega, F. B., Veiga, O. L., Moliner-Urdiales, D., Mauro, B., \& Sjöström, M. (2010). Recommended Levels of Physical Activity to Avoid an Excess of Body Fat in European Adolescents. American Journal of Preventive Medicine, 39(3), 203-211

McKenna, M.L., (2010). Options to Support Healthy Eating in Schools. Canadian Journal of Public Health, 101(2), 14-17.

Meireles, A. L., Xavier, C. C., de Souza Andrade, A. C., Proietti, F. A., \& Caiaffa, W. T. (2015). Self-rated health among urban adolescents: the roles of age, gender, and their associated factors. PLoS One, 10(7).

Moller, N. C., Tarp, J., Kamelarczyk, E. F., Brønd, J. C., Klakk, H., \& Wedderkopp, N. (2014). Do extra compulsory physical education lessons mean more physically active children - findings from the childhood health, activity, and motor performance school study Denmark (The CHAMPS-study DK). International Journal of Behavioral Nutrition and Physical Activity, 11(1). 
Moreno, L. A., Gottrand, F., Huybrechts, I., Ruiz, J. R., González-Gross, M., \& DeHenauw, S. (2014). Nutrition and Lifestyle in European Adolescents: The HELENA (Healthy Lifestyle in Europe by Nutrition in Adolescence) Study. Advances in Nutrition, 5(5), 615S-623S.

Noguchi, M., Murayama, Y., Kume, M., Harada, M., \& Iizuka, Y. (2018). The eating habits of mothers and their pre-school children in Japan. Revue d'Épidémiologie et de Santé Publique, 66, S349.

Oneț A., Ilieș, D.C., Ilieș, A., Herman, G.V., Burta, L., Marcu, F., Buhas, R., Caciora, T., Baias, Ș., Oneț, C., Ilieș, M., Lincu, A. (2020). Indoor air quality assessment and its perception. Case study - historic wooden church, Romania. Romanian Biotechnological Letters, in published. https://romanianbiotechnologicalletters.files.wordpress.com/2019/02/ilies-et-al.pdf

Owens, J. (2014). Insufficient Sleep in Adolescents and Young Adults: An Update on Causes and Consequences. PEDIATRICS, 134(3), e921-e932.

Papp, B.M., Șerbescu, C., Caciora, T., Baidog, A., Varodi, M.O. (2019). The Effects of a Physical Activity Program on Body Composition and Physical Condition in the Overweight Adult. Analele Universităţii din Oradea. Fascicula Educaţie Fizică şi Sport, 29(1), 1-9.

Peralta, L. R., Dudley, D. A., \& Cotton, W. G. (2016). Teaching Healthy Eating to Elementary School Students: A Scoping Review of Nutrition Education Resources. Journal of School Health, 86(5), 334-345.

Peres, M., Masiero, A.V., Longo, G.Z., Rocha, G.C., Matos, I.B., Najnie, K., Oliveira, M., Arruda, M., Peres, K., (2010), Self-rated health among adults in Southern Brazil. Revista de saúde pública, 44, 901-11.

Porter, K. J., Koch, P. A., \& Contento, I. R. (2017). Why and How Schools Make Nutrition Education Programs “Work." Journal of School Health, 88(1), 23-33.

Post, G. B., Vente, W. de, Kemper, H. C. G., \& Twisk, J. W. R. (2001). Longitudinal trends in and tracking of energy and nutrient intake over 20 years in a Dutch cohort of men and women between 13 and 33 years of age: The Amsterdam growth and health longitudinal study. British Journal of Nutrition, 85(03), 375-385.

Powell, L. M., \& Nguyen, B. T. (2013). Fast-Food and Full-Service Restaurant Consumption Among Children and Adolescents. JAMA Pediatrics, 167(1), 14-20.

Pulido-Arjona, L., Correa-Bautista, J. E., Agostinis-Sobrinho, C., Mota, J., Santos, R., Correa-Rodríguez, M., ... Ramírez-Vélez, R. (2018). Role of sleep duration and sleep-related problems in the metabolic syndrome among children and adolescents. Italian Journal of Pediatrics, 44(1).

Rosen, L. D., Lim, A. F., Felt, J., Carrier, L. M., Cheever, N. A., Lara-Ruiz, J. M., ... Rokkum, J. (2014). Media and technology use predicts ill-being among children, preteens and teenagers independent of the negative health impacts of exercise and eating habits. Computers in Human Behavior, 35, 364-375

Salam, R. A., Hooda, M., Das, J. K., Arshad, A., Lassi, Z. S., Middleton, P., \& Bhutta, Z. A. (2016). Interventions to Improve Adolescent Nutrition: A Systematic Review and Meta-Analysis. Journal of Adolescent Health, 59(4), S29-S39.

Schneider, D. (2000). International trends in adolescent nutrition. Social Science \& Medicine, 51(6), 955-967.

Short, M. A., Gradisar, M., Wright, H., Lack, L. C., Dohnt, H., \& Carskadon, M. A. (2011). Time for Bed: Parent-Set Bedtimes Associated with Improved Sleep and Daytime Functioning in Adolescents. Sleep, 34(6), 797-800.

Sila, S., Ilić, A., Mišigoj-Duraković, M., Sorić, M., Radman, I., \& Šatalić, Z. (2019). Obesity in adolescents who skip breakfast is not associated with physical activity. Nutrients, 11(10), 2511.

Tătar, C.F., Herman, G. V., \& Pețan, P. (2018). Sport and physical activity engagement in Romania. Geosport for Society, 8(1), 40-50.

Townsend, N., Murphy, S., \& Moore, L. (2010). The more schools do to promote healthy eating, the healthier the dietary choices by students. Journal of Epidemiology \& Community Health, 65(10), 889-895.

US National Sleep Foundation, (2000), Adolescent sleep needs and patterns, Washington D.C. USA.

Utter, J., Denny, S., \& Dyson, B. (2016). School gardens and adolescent nutrition and BMI: Results from a national, multilevel study. Preventive Medicine, 83, 1-4.

Verburgh, L., Königs, M., Scherder, E. J. A., \& Oosterlaan, J. (2013). Physical exercise and executive functions in preadolescent children, adolescents and young adults: a meta-analysis. British Journal of Sports Medicine, 48(12), 973-979.

Viner, R. M., Ozer, E. M., Denny, S., Marmot, M., Resnick, M., Fatusi, A., \& Currie, C. (2012). Adolescence and the social determinants of health. The Lancet, 379(9826), 1641-1652. 
Vlăsceanu, L. (2013). Introduction in methodology of sociological research, Polirom Publishing House, Iași (in Romanian).

Washi, S. A., \& Ageib, M. B. (2010). Poor diet quality and food habits are related to impaired nutritional status in 13- to 18-year-old adolescents in Jeddah. Nutrition Research, 30(8), 527-534.

Wendt, A.J., Buhaș, R., Herman G.V. (2019). Experience of the Baile-Felix Tourist System (Romania) For the Protection and Promotion of the Grey Seal as a Brend on the Hel Peninsular (Poland). Baltic Region/Baltijskij Region, 11(1), 109-116.

Wyness, L. (2015). The role of red meat in the diet: nutrition and health benefits. Proceedings of the Nutrition Society, 75(03), 227-232. 